\title{
Injustice Perception and Work Alienation: Exploring the Mediating Role of Employee's Cynicism in Healthcare Sector
}

\author{
Omar DURRAH ${ }^{1}$
}

Received: June 22, 2020 Revised: July 12, 2020 Accepted: August 10, 2020

\begin{abstract}
The aim of this study is to explore the effect of injustice perception on work alienation and the mediating role played by the employee's cynicism between injustice perception and work alienation in the healthcare sector in Oman. By utilizing a simple random sampling technique, data were collected using a questionnaire consisting of 306 nurses working in private healthcare providing organizations in Oman. The collected data was then analyzed using AMOS program through the Structural Equation Modeling (SEM). The results of study show that the levels of perception of injustice and cynicism of nurses in the private healthcare centers were low, while the work alienation was found to be at moderate level in these healthcare organizations. The findings of the empirical study reveal that injustice perception and employee's cynicism significantly affect work alienation. The impact of injustice perception in creating employee's cynicism was also observed. The hypothesis that the mediating role played by employee's cynicism in injustice perception and work alienation relationship was partially supported. Moreover, injustice perception and cynicism directly affect work alienation, therefore, these hospitals should consider organizational policies and procedures to achieve equality and justice among nursing personnel, and to eliminate the factors that cause cynicism and work alienation.
\end{abstract}

Keywords: Healthcare Sector, Injustice Perception, Work Alienation, Employee's Cynicism, Sultanate of Oman.

JEL Classification Code: M10, M12, I14, O15

\section{Introduction}

Human resource management plays the most vital role in managing the employees in any organization (Tulsi \& $\mathrm{Ji}, 2020$ ). Human resource is a significant element for all organizations. Humans are the complex element in an organization as they pose a risk to organizational survival or failure due to complex mindset (Valikhani \& Zamani, 2019). The inappropriate and unacceptable human resource policies and procedures in an organization pose grim threat to organizational stability and productivity and are a serious challenge for future organizations and firms. Hence, the most

${ }^{1}$ First Author and Corresponding Author. Assistant Professor, Management Department, College of Commerce and Business Administration, Dhofar University, Sultanate of Oman [Postal Address: P.O Box. 2509, Salalah, 211, Sultanate of Oman]

Email: odurrah@du.edu.om

(c) Copyright: The Author(s)

This is an Open Access article distributed under the terms of the Creative Commons Attribution Non-Commercial License (https://creativecommons.org/licenses/by-nc/4.0/) which permits unrestricted non-commercial use, distribution, and reproduction in any medium, provided the original work is properly cited. important risk to the human resources of an organization is the psychological characteristics of its employees, work alienation, work pressure and unfairness (Afrasiabi, 2013).

The injustice or unfairness in an organization affects the employees' behavior, psychology and the health (Elovainio et al. 2004). The unfair dealings by the organization or a decision-maker can provoke injustice perception (Kickul et al, 2005). The employees may experience increased work stress. The injustice perception causes lack of control and might force the affecters to modify the source causing stress (Ceylan \& Sulu, 2010). In psychological studies the injustice perception was studied with special emphasis on relationship of employees with their organizations (Haslam, 2004). However, they should be concerned as employees' attitude and behaviors affect their performance. Thus, the employers should not risk their employees being alienated (Sookoo, 2014). Many studies have been done lately that focus on the relationship between injustice perceptions and alienation dynamics (Sookoo, 2014; Sulu et al, 2010). Perception of injustice has an important effect on work alienation (Dajani \& Mohamad, 2017; Merkhe, 2015). However, some of the research proved that the injustice perception might play a crucial role in few organizational 
processes such as organizational cynicism (Ahmed, Kiyani, and Hashmi, 2013), organizational commitment (Sulu et al, 2010), job stress (Ceylan \& Sulu, 2010), motivation (Zellars et al., 2004), and psychological health (Schmitt \& Dorfel, 1999). Joe-Akunne and Oguegbe (2019) highlighted that the increase in organizational cynicism and the interactional injustice causes an elevated workplace deviance among the employees. Cynicism is mostly related with one's negative attitude towards the organization they work in that has cognitive, affective and behavioral dimensions (Dean et al, 1998). Yıldıza and Şaylıkay (2014) confirmed the extent to which organizational cynicism is linked to work alienation. Koçoglu (2014) determined the relationship between work alienation and cynicism.

Previous studies show evidence of the relationship between alienation and injustice (Ceylan \& Sulu, 2010); however, the relation between these variables is still uncertain (Merkhe, 2015). There is a need of determining the facts that support this relationship. The research in this area is still limited and there is a need to perform extensive research to identify this relationship. Most of the research in this field falls within the European context and ignores the Gulf context, which has a lot of growth potential. Moreover, fewer experimental studies are performed in the field of injustice perception, organizational cynicism and work alienation, thus opening boundaries for potential research. The present study is an attempt to explore this research area for potential benefits. Moreover, it is also done to provide an in-depth understanding of the injustice perception and its impact on cynicism and alienation of employees; specifically, within the perspective of Omani health sector. Overall, the following research questions were addressed: (1) the extent to which the injustice perception affects work alienation in health sector of Oman; (2) the role played by employee's cynicism in relation to injustice perception and work alienation in health sector of Oman.

\section{Literature Review}

\subsection{Injustice Perception}

The theory of equity as presented by Adams (1965) is built on the evaluation of supposed inputs to outputs. When an employee thinks his contributions or efforts (inputs) are not rewarded and the outputs are not equal to those around him, he may feel dissatisfied that might result in absenteeism and turnover intention. Also, Adams (1965) noted that when the employee perceives psychological inequity, he suffers severe emotional strain and make an effort to restore equity. Several studies (Joe-Akunne \& Oguegbe, 2019; Tucker, 1993; Crino, 1994) have cited injustice as the antecedent of negative behaviors. Ahmed and colleagues (2013) indicate that the injustice perceptions result in strong reactions and causes deviant work behavior in organization. Kelloway and colleagues (2006) proposed that injustice is the employee's perception and faith of being treated unjustly leading to negative behavior. Furthermore, this perception of unfairness may lead to deviant work behavior by employees (Aquino et al, 1999; Fox et al, 2001).

Jones (2008) found that the employees have desire for revenge as a reaction to perceived injustice. Skarlicki and colleagues (2008) suggested that the employee's perception of injustice stimulates sabotage; a form of revenge. Moreover, Furnham and Segal (2011) revealed the employees facing unfair treatment due to organizational injustice become unhappy and dissatisfied with their work and management. This dissatisfaction threatens the organization. Merkhe (2015) indicates that the negative emotions of employees i.e., depression, anger, anxiety, etc., are result of injustice that encourages such attitudes embodied within the withdrawal behavior causing work alienation, low commitment, cynicism, absenteeism, fake excuses for sick leaves and intention to leave work (Mingzheng et al, 2014).

Organizational injustice has three components, namely, distributive injustice, interactional injustice and procedural injustice (Ceylan \& Sulu, 2010; Joe-Akunne \& Oguegbe, 2019; Merkhe, 2015). (1) Distributive Injustice is judged by comparing and evaluating the outputs to an outcome, rule or standard, for e.g., past experiences or a co-worker (Hubbel \& Chory-Assad, 2005). Employee perception for distributive injustice occurs when their benefits and rewards are not equal to their efforts (Colquitt et al, 2005). Sulu et al. (2010) claimed that, when workers face distributive injustice, they are more likely to check if the distribution process is fair and unbiased. Greenberg (2004) indicates that the unfair distribution of resources in an organization causes sense of isolation and weakness among workers. (2) Procedural Injustice is the unfairness perceived concerning the decision-making procedures. It is a significant precursor of numerous behaviors and attitudes (Ceylan \& Sulu, 2010). Employee perceives that the procedural injustice is an agent that produces psychological distress (Tepper, 2001). The employees start thinking that they don't have an authority to participate in decision-making process due to perceived procedural injustice. Hence, this uncertainty and feeling of lack of control in the decision-making procedures causes stress among workers (Ceylan \& Sulu, 2010). It also develops a sense of weakness and isolation among the employees who are not a part of decision-making process and are not heard (Ceylan \& Sulu, 2011). Thus, such unfair practices cause inferiority complex among workers and increases the feelings of worthlessness and work alienation (Sulu et al, 2010). Employees who perceive that their organization has unjust or discriminating procedures will more likely develop more feelings of social isolation (Sulu et al 2010). (3) Interactional Injustice concerns the individual's perception of the treatment experienced personally during organizational day-to-day 
operations (Bies \& Moag, 1986). The employees display concern and interest over the treatment received from higher authorities along with the appropriateness of explaining the formal decision making processes (Joe-Akunne \& Oguegbe, 2019). The interpretation of interactional injustice is dealt with in the theory of reciprocity norm and social exchange (Cropanzano \& Mitchell, 2005). From the perspective of the social exchange, employees expect fair, courteous, truthful, and honest treatments from their organization. While, from the perspective of the reciprocity norm, employees perceiving feelings of fair treatments are more expected to display sincere commitment to the goals and values of their organizations (Cohen-Charash \& Spector, 2001).

\subsection{Employee's Cynicism}

Cynicism prevails among organizations globally. It is an old phenomenon that has been the center of debate among employees and employers in organizations. (Durrah et al, 2019). Lately, it has appeared as a new style of employer-employee relationship in firms (Feldman, 2000). Cynicism develops when an employee develops feelings of untrustworthiness and diffidence towards his organization (Ajzen, 2001). The cynicism is more often defined by the sentiments like disappointment or anger that affect behavior, beliefs and attitudes. (Andersson \& Bateman, 1997; Abraham, 2000; Pugh et al., 2003).

Dean and Dharwadkar (1998) defined cynicism as negative behavior in an organization that is characterized by (1) belief about the insufficient integration environment in an organization, (2) negative feelings for the organization, and (3) tendency of showing the abusive behavior towards the organization. Ozler and Atalay (2011) describe the cynicism as an individual's feeling of dissatisfaction and frustration for an organization and the belief that the honesty, transparency, integrity, and justice is lacking in organization's management. Subgur et al., (2019) explained the cynicism as an innate personality attribute that reflects negative sentiments and sensitivities like frustration and has dreadful consequences towards the organization. Yıldıza and Şaylıkay (2014) defined the organizational cynicism as an important specific or general employees' attitude that the organization lacks honesty thus resulting in negative emotions, beliefs and other related behaviors. Andersson \& Bateman (1997) indicate that the cynicism is an attitude that is eminent by distrust and dislike for others. It involves disillusionment, frustration, distrust, and negative feelings towards a group, institution or a person. In brief, organizational cynicism refers to suspicion or an uncertainty towards the management (Li \& Fan Zhou, 2011).

The cynicism concept has "cognitive, affective and behavioral" components. (Çetinkaya, 2018; Stanley, John, \& Laryssa, 2005; Tukeltürk, Perçin, \& Guzel, 2012).
(1) The cognitive component is that the employee senses lack of integrity, honesty and sincerity in the organization. The employee believes that their personal values and goals are not in accordance with the goals and values of the organization (Bernerth et al., 2007). (2) The affective component consists of powerful sentimental and emotional reactions of employees towards the organization. The employee feels negative emotions like fury, revulsion, disgrace, anger, tension, discomfort, anxiety and hatred towards their employer (Helvaci \& Cavdar, 2017). (3) The behavioral component consists of critical expressions and negative tendencies towards the organization. This powerful criticism can take various forms, such as humor and hurtful attitudes, bad mouthing and pessimistic predictions about the organization's work in the future (Rehan et al., 2017).

\subsection{Work Alienation}

Alienation as a concept that dates back to the $19^{\text {th }}$ century when its 'founding fathers' Hegel and Marx first introduced it. Psychologists, sociologists and other social scientists have used the concept of alienation in numerous studies. (Tummers \& den Dulk, 2013). Alienation is one of the social phenomena, which in most cultures is known as crisis, damage, or a social problem in a vast range of issues, like philosophy, sociology, theology, psychiatry and psychology (Farahbod et al., 2012). The idea of work alienation and its effect has caught the attention of researchers and scholars for a long time (Geyer, 1996; Hegel, 2003). Karl Marx has explained work alienation with respect to the rise of capitalism and has studied it as an independent concept, whereas the contemporary scholars have studied subjective work alienation to identify the extent to which employees feel alienation from work (Kanungo, 1982).

The alienation concept can be defined as "the disruption, the natural interactions between the individuals and between the individuals and their illusion" (Valikhani \& Zamani, 2019). Kobasa et al., (1982) defined work alienation as "a representation of an unenthusiastic attitude toward the work that indicates a low level of engagement with the job role". Alienation is considered as an unwanted issue imposed on the people by the social system. It has many consequences; interrupts interpersonal relationships in the organizations, reduces the participation in social networks, causes suspicion in the workplace, weakens social relations and makes the employee not only dissatisfied but also unmotivated towards his job (Tabrizi, 1991). The employees suffering from work alienation feel stranger in their organization. They lack selfconsciousness and self-awareness, hence, they act under the influence of any external forces that motivate them (Khdour, Durrah, \& Harris, 2015: Farahbod et al., 2012). In case of alienation, the individual does not focus on his works and related activities, hence, cannot demonstrate or develop his 
various existential talents. Such an individual misses the sense of happiness and is unable to raise his body and mind freely, because for him work has an imposed and compulsory aspect, and is not necessary for satisfaction, but a means to satisfy the needs of others (Valikhani \& Zamani, 2019).

Seeman (1971) determined five components of alienation, i.e., powerlessness, meaninglessness, normality, loneliness, and self-estrangement. Hackman and Oldham (1980) added terms like disaffection, boredom, estrangement, psychological and emotional abandonment with work alienation concept. Tummers (2011) used powerlessness and meaninglessness that are the two aspects of alienation. DeHart-Davis and Pandey (2005) also considered these dimensions as the vital components of work alienation. Additionally, a number of researchers have utilized Seeman's classification in investigating the work alienation concept (Dağlı and Averbek, 2017; Özer et al., 2019; Sanal \& Zare, 2017; Valikhani \& Zamani, 2019). Hence, it is considered as a multidimensional concept (Mau, 1992; Tummers et al., 2015). Likewise, researchers conceptually associated work alienation with low levels of positive psychological stimulation pertaining to job responsibilities and the work environment (Hull, Van Treuren, \& Virnelli, 1987). It is also linked to the disinterestedness from the work in organization (Hirschfeld \& Feild, 2000).

\subsection{Study Model and Hypotheses}

Considering the research literature (Ceylan \& Sulu, 2011; Dajani \& Mohamad, 2017; Yıldıza \& Şaylıkay, 2014; Sazkaya, 2014), the aim of this study was to develop a study model as shown in Figure 1. The hypotheses developed to support this study were:

$\boldsymbol{H}_{I}:$ Injustice perception has a significant effect on work alienation in health sector.

$\boldsymbol{H}_{2}$ : Injustice perception has a significant effect on employee's cynicism in health sector.
$\boldsymbol{H}_{3}:$ Employee's cynicism has a significant effect on work alienation in health sector.

$\boldsymbol{H}_{4}$ : Employee's cynicism plays a mediating role in injustice perception and work alienation relationship in health sector.

\subsection{The Context}

The health system in the Sultanate of Oman is providing healthcare facilities to both citizens and expatriates. The aggregate spending on healthcare sector in Oman approximates to around $2.7 \%$ of the GDP, while the percapita health expenditures are around \$591 (Planning Agency, 2014). The government mainly funds the healthcare system by spending close to $81.1 \%$, the private healthcare sector spends $11.6 \%$ while the insurance companies and business owners contributes to around $7.3 \%$ of the total healthcare expenditures (WHO, 2013).

The primary provider of healthcare in Oman is the Ministry of Health $(\mathrm{MoH})$ that is responsible to ensure the availability and applicability of healthcare practices and policies along with monitoring its implementation. Other services that provide healthcare in the Sultanate include the medical section of the armed forces, the Royal Diwan, Royal Oman Police, Oman Petroleum Development Company, the Sultan Qaboos University Hospital and the private sector (Information and Statistics Department, 2012). Statistics related to private healthcare institutions in the Sultanate of Oman showed that there are 25 private hospitals, 232 private clinics and healthcare complexes, 289 dental clinics, 51 Chinese and Indian medicine clinics and 672 private pharmacies. The workforce in the private healthcare sector reached 13546, including 1138 specialist doctors, 1214 general doctors, 1048 dentists, 1999 pharmacists, 4072 nurses and 590 laboratory technicians whereas the number of beds reached 908 (Annual Health Report, 2018).

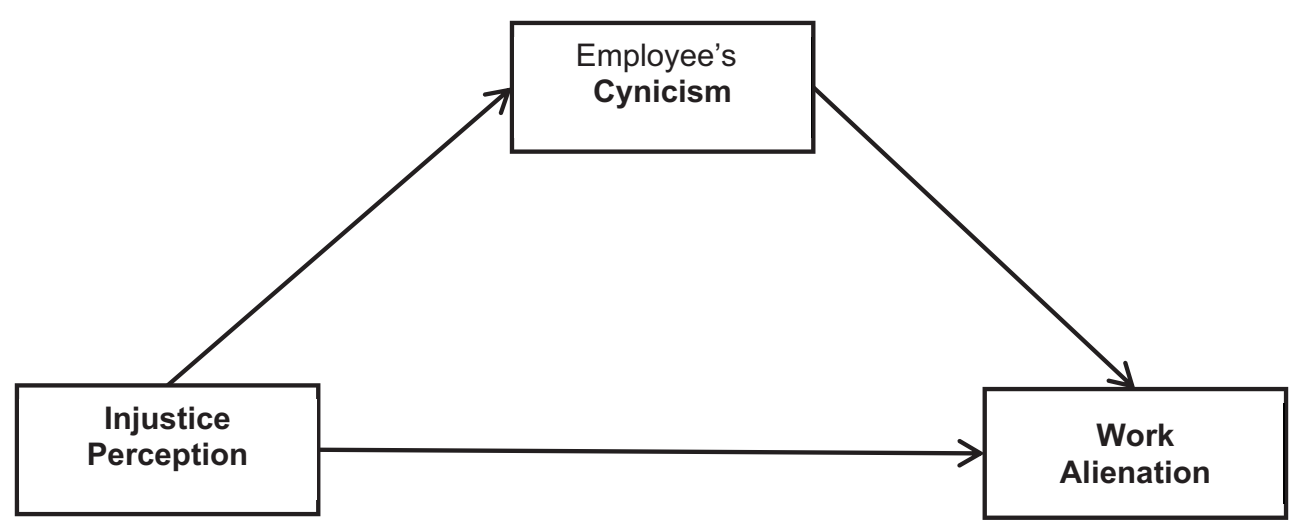

Figure 1: Proposed study model 


\section{Methodology}

\subsection{Sample and Procedure}

The healthcare sector is one of the key growth sector contributing to the economy of a country. Considering this, many researchers try to solve problems related to this sector, while also trying to figure out the methods to achieve greater success (Sulu \& Ceylan, 2010). This is an empirical study done to define the influence of injustice perception on work alienation and the mediator role of employee's cynicism between injustice perception and work alienation in the healthcare sector in Oman. The target study population was nurses in four private hospitals - Badr Alsama, Alhakim, Alrrazi, and Lia in Salalah, Oman. These four hospitals were selected as they represent the largest healthcare centers in the region. The target respondents for the study were 4,072 nurses in private hospitals. Using a simple random sampling technique, the fit sample size selected was 352 . The data was collected by distributing 352 questionnaires among the study sample, however, only 306 subjects responded. The collected data was analyzed by an AMOS software using structural equation modeling.

\subsection{Measures}

A 3-section questionnaire was designed to study the research variables. Injustice perception was measured on a scale of 4 items developed by Dajani and Mohamad (2017). Work alienation was assessed using a 5-item scale developed by Punia and Berwal (2017), while a 3-item scale adapted from Durrah, Chaudhary, and Gharib (2019) was used to assess employee's cynicism. A 5-point Likert scale ranging from strongly disagree (1) to strongly agree (5) was used.

\subsection{Respondents Characteristics}

The demographic characteristics of respondents in the current study showed that $64.32 \%$ of the sample respondents were females and $46.68 \%$ of the respondents were males. $45.73 \%$ of the sample were young with age range between 30 and 40 . The majority of the sample population had a bachelor degree $(56.39 \%)$ whereas $68.74 \%$ of the sample population had work experience above five years.

\section{Data Analysis and Findings}

\subsection{Exploratory Study}

To determine the current study variables, the exploratory factor analysis (EFA) has been performed using SPSS software. Varimax rotation was used to adjust data coordinates from principal component analysis. Three factors were obtained; the first one was called injustice perception (IP) (four items), the second one was called employee's cynicism (EC) (three items), and the third one was called work alienation (WA) (five items) as shown in Table 1.

All conditions of exploratory factor analysis (EFA) were achieved, i.e., the Cumulative Variance $=67.276$ $>60$; Bartlett's Test $=1540.655$, with significance level equal to $.000<.05 ; \mathrm{KMO}=.710>.60$; and Eigenvalues for each factor more than 1 (Ghouse, McElwee, \& Durrah, 2019). Each item of the study variables was loaded more than 0.40 (Straub et al, 2004; Dwivedi, Choudrie, \& Brinkman, 2006) that signifies that the EFA was suitable to use for the data collected (Ambulkar, Blackhurst, \& Grawe, 2015).

Table 1: Exploratory factor analysis (EFA) of the study model

\begin{tabular}{|c|c|c|c|c|c|c|}
\hline \multirow{2}{*}{ Factors } & \multicolumn{2}{|c|}{ First Factor } & \multicolumn{2}{|c|}{ Second Factor } & \multicolumn{2}{|c|}{ Third Factor } \\
\hline & \multicolumn{2}{|c|}{ Injustice Perception (IP) } & \multicolumn{2}{|c|}{ Employee's Cynicism (EC) } & \multicolumn{2}{|c|}{ Work Alienation (WA) } \\
\hline \multirow{5}{*}{ Items and Loadings } & $\mathrm{IP}_{1}$ & .902 & $\mathrm{EC}_{1}$ & .725 & $\mathrm{WA}_{1}$ & .713 \\
\hline & $\mathrm{IP}_{2}$ & .734 & $\mathrm{EC}_{2}$ & .841 & $\mathrm{WA}_{2}$ & .841 \\
\hline & $\mathrm{IP}_{3}$ & a.929 & $\mathrm{EC}_{3}$ & .824 & $\mathrm{WA}_{3}$ & .733 \\
\hline & $\mathrm{IP}_{4}$ & .637 & & & $\mathrm{WA}_{4}$ & .771 \\
\hline & & & & & $\mathrm{WA}_{5}$ & .789 \\
\hline Eigen Value & \multicolumn{2}{|c|}{3.115} & \multicolumn{2}{|c|}{2.856} & \multicolumn{2}{|c|}{2.102} \\
\hline Variance & \multicolumn{2}{|c|}{25.962} & \multicolumn{2}{|c|}{23.801} & \multicolumn{2}{|c|}{17.513} \\
\hline Cumulative Variance & \multicolumn{2}{|c|}{25.962} & \multicolumn{2}{|c|}{49.763} & \multicolumn{2}{|c|}{67.276} \\
\hline \multicolumn{5}{|c|}{ KMO - Kaiser-Meyer-Olkin Measure of Sampling Adequacy } & \multicolumn{2}{|c|}{.710} \\
\hline \multicolumn{3}{|c|}{ Bartlett's Test of Sphericity } & \multicolumn{2}{|c|}{ Sig. (.000) } & \multicolumn{2}{|c|}{1225.548} \\
\hline
\end{tabular}


After identifying the factors by EFA, the descriptive statistics for study variables (means, standard deviations, reliability, skewness, kurtosis, and communalities) have been conducted as shown in Table 2 .

The results in Table 2 indicate that the mean of injustice perception was at a low level $(\overline{\mathrm{x}}=2.587$ with $\sigma=.8600)$. Similarly, the mean of employee's cynicism was also at a low level $(\overline{\mathrm{x}}=2.753$ with $\sigma=.7999)$, whereas the mean of work alienation was at moderate level $(\overline{\mathrm{x}}=3.387$ with $\sigma=.8312$ ). Moreover, the results of Cronbach's Alpha $(\alpha)$ for variables of the study showed that the scale utilized in the current study is reliable because the values were within the acceptable range, which is above (.60) (Durrah et al., 2020b; Hair et al., 2006). The values for injustice perception has $\alpha=.853$, employee's cynicism $\alpha=.784$ and work alienation has $\alpha=.847$.

Normality test of the study variables has been performed using skewness and kurtosis statistics. The results mentioned in the above table indicate that all values were between +3 and -3 i.e. within the acceptable range (Ghasemi \& Zahediasl, 2012). Moreover, the communalities in Table 2 are considered to be ideal because all values are above 0.5 , which indicate that the better representation of variables by the extracted components (Field, 2005).

Table 2: Descriptive analysis, assessment of normality, and communalities

\begin{tabular}{|c|c|c|c|c|c|c|c|}
\hline Variable & Item & Mean & St.D. & $\alpha$ & Skewness & Kurtosis & Communalities \\
\hline \multirow{4}{*}{$\begin{array}{l}\text { Injustice } \\
\text { Perception (IP) }\end{array}$} & IP1 & \multirow{4}{*}{2.587} & \multirow{4}{*}{.8600} & \multirow{4}{*}{.853} & .380 & -.658 & .823 \\
\hline & IP2 & & & & .377 & -.916 & .601 \\
\hline & IP3 & & & & .511 & -.610 & .883 \\
\hline & IP4 & & & & .525 & -1.150 & .596 \\
\hline \multirow{3}{*}{$\begin{array}{l}\text { Employee's } \\
\text { Cynicism } \\
\text { (EC) }\end{array}$} & EC1 & \multirow{3}{*}{2.753} & \multirow{3}{*}{.7999} & \multirow{3}{*}{.784} & -.966 & -.029 & .651 \\
\hline & EC2 & & & & -1.815 & 2.522 & .741 \\
\hline & EC3 & & & & -.678 & -.308 & .687 \\
\hline \multirow{5}{*}{$\begin{array}{l}\text { Work Alienation } \\
\text { (WA) }\end{array}$} & WA1 & \multirow{5}{*}{3.387} & \multirow{5}{*}{.8312} & \multirow{5}{*}{.847} & .380 & -.860 & .614 \\
\hline & WA2 & & & & .582 & -.591 & .724 \\
\hline & WA3 & & & & .852 & -.127 & .570 \\
\hline & WA4 & & & & .563 & -.399 & .635 \\
\hline & WA5 & & & & .666 & -.349 & .648 \\
\hline
\end{tabular}

Table 3: One factor model (CMV).

\begin{tabular}{|c|c|c|c|c|c|c|}
\hline \multirow{2}{*}{ Component } & \multicolumn{3}{|c|}{ Initial Eigenvalues } & \multicolumn{2}{c|}{ Extraction Sums of Squared Loadings } \\
\cline { 2 - 7 } & Total & \% of Variance & Cumulative \% & Total & $\%$ of Variance & Cumulative \% \\
\hline 1 & 4.072 & 33.935 & 33.935 & 4.072 & 33.935 & 33.935 \\
\hline 2 & 2.261 & 18.840 & 52.775 & & & \\
\hline 3 & 1.740 & 14.501 & 67.276 & & & \\
\hline 4 & .761 & 6.339 & 73.615 & & & \\
\hline 5 & .681 & 5.677 & 79.292 & & & \\
\hline 6 & .607 & 5.058 & 84.350 & & & \\
\hline 7 & .512 & 4.270 & 88.620 & & & \\
\hline 8 & .464 & 3.870 & 92.490 & & & \\
\hline 9 & .351 & 2.925 & 95.416 & & & \\
\hline 10 & .270 & 2.247 & 97.662 & & & \\
\hline 11 & .179 & 1.492 & 99.155 & & & \\
\hline 12 & .101 & .845 & 100.000 & & & \\
\hline
\end{tabular}


To identify the common method bias detected in this research, Harman's one factor test was used as a corrective measure (Bish et al., 2015). Using the principal component analysis, all the 12 items were loaded into one common factor. Table 3 showed that the total variance is $33.935 \%$ that is less than the assumed threshold point $<50 \%$ (Podsakoff, MacKenzie, \& Podsakoff, 2012). Hence, the common method bias was found to have no significant effect on the collected data in this study.

\subsection{Confirmatory Study}

Confirmatory factor analysis (CFA) was used to identify the extent to which the number of measured variable represents constructs. The results in Table 4 indicate that all indices of fit were found to be within the satisfactory range (Hu \& Bentler, 1999).

Table 4 shows CFA results, which indicate how the convergent validity was determined. The composite reliability of constructs yielded greater than 0.70 (Chan, 2015); i.e. IP $=.929, \mathrm{EC}=.840$, and $\mathrm{WA}=.882$ that was confirmed by the test of average variance explained (AVE), i.e., all the constructs were above the acceptable level of 0.50 (Bagozzi
$\& \mathrm{Yi}, 1988)$; i.e. $\mathrm{IP}=.554, \mathrm{EC}=.637,510$, and $\mathrm{WA}=.550$. Furthermore, the values of square multiple correlation (SMC) listed in Table 4 exceeded the acceptable level of 0.30 (Durrah et al, 2020a) and the values of standardized factor loadings (SFL) were more than 0.50 (Hair et al, 2010).

The value of square roots of (AVE) in each column should be more than correlation values, which is listed in that column (Alraja \& Kashoob, 2019). The results shown in Table 4 confirm that the adequate discriminant validity has been achieved. Moreover, all the variables were found to be significantly and positively correlated to each other at the level of significance 0.01 .

\subsection{Testing the Structural Model}

Preacher and Hayes (2008) suggested applying structural equation modeling (SEM) to test the study model. For examining mediation two models were tested using AMOS software. The direct effect of injustice perception on work alienation is examined in Model A, shown in Figure 2 and the indirect effect through employee's cynicism and the relationship between injustice perception and work alienation examined in Model B, shown in Figure 3.

Table 4: Confirmatory factor analysis results (CFA) and discriminant analysis

\begin{tabular}{|c|c|c|c|c|c|c|c|c|c|}
\hline \multirow[b]{2}{*}{ Constructs } & \multicolumn{3}{|c|}{ Injustice Perception (IP) } & \multicolumn{3}{|c|}{ Employee's Cynicism (EC) } & \multicolumn{3}{|c|}{ Work Alienation (WA) } \\
\hline & Items & $\begin{array}{c}\text { Square } \\
\text { Multiple } \\
\text { Correlation } \\
\text { SMC }>.30\end{array}$ & $\begin{array}{c}\text { Standardized } \\
\text { Factor } \\
\text { Loadings } \\
\text { SFL }>.50\end{array}$ & Items & $\begin{array}{c}\text { Square } \\
\text { Multiple } \\
\text { Correlation } \\
\text { SMC > }>30\end{array}$ & $\begin{array}{c}\text { Standardized } \\
\text { Factor } \\
\text { Loadings } \\
\text { SFL }>.50\end{array}$ & Items & $\begin{array}{c}\text { Square } \\
\text { Multiple } \\
\text { Correlation } \\
\text { SMC }>.30\end{array}$ & $\begin{array}{c}\text { Standardized } \\
\text { Factor } \\
\text { Loadings } \\
\text { SFL > .50 }\end{array}$ \\
\hline \multirow{5}{*}{ Loadings } & $\mathrm{IP}_{1}$ & .803 & .896 & $\mathrm{EC}_{1}$ & .500 & .707 & $\mathrm{WA}_{1}$ & .495 & .704 \\
\hline & $\mathrm{IP}_{2}$ & .314 & .560 & $\mathrm{EC}_{2}$ & .708 & .841 & $\mathrm{WA}_{2}$ & .659 & .812 \\
\hline & $\mathrm{IP}_{3}$ & .969 & .985 & $\mathrm{EC}_{3}$ & .371 & .609 & $\mathrm{WA}_{3}$ & .465 & .682 \\
\hline & $\mathrm{IP}_{4}$ & .314 & .560 & & & & $\mathrm{WA}_{4}$ & .467 & .684 \\
\hline & & & & & & & $\mathrm{WA}_{5}$ & .517 & .719 \\
\hline $\begin{array}{l}\text { Composite } \\
\text { Reliability } \\
\text { CR > .70 }\end{array}$ & \multicolumn{3}{|c|}{.929} & \multicolumn{3}{|c|}{.840} & \multicolumn{3}{|c|}{.882} \\
\hline $\begin{array}{l}\text { Average } \\
\text { Variance } \\
\text { Explained } \\
\text { AVE > .50 }\end{array}$ & \multicolumn{3}{|c|}{.554} & \multicolumn{3}{|c|}{.637} & \multicolumn{3}{|c|}{.550} \\
\hline$(\mathrm{IP})$ & \multicolumn{3}{|c|}{$(.744)$} & & & & & & \\
\hline$(\mathrm{EC})$ & \multicolumn{3}{|c|}{$.258^{* *}$} & \multicolumn{3}{|c|}{$(.798)$} & & & \\
\hline (WA) & \multicolumn{3}{|c|}{$.252^{* *}$} & \multicolumn{3}{|c|}{$.256^{\star *}$} & \multicolumn{3}{|c|}{$(.741)$} \\
\hline
\end{tabular}

**. Correlation is significant at the 0.01 level 


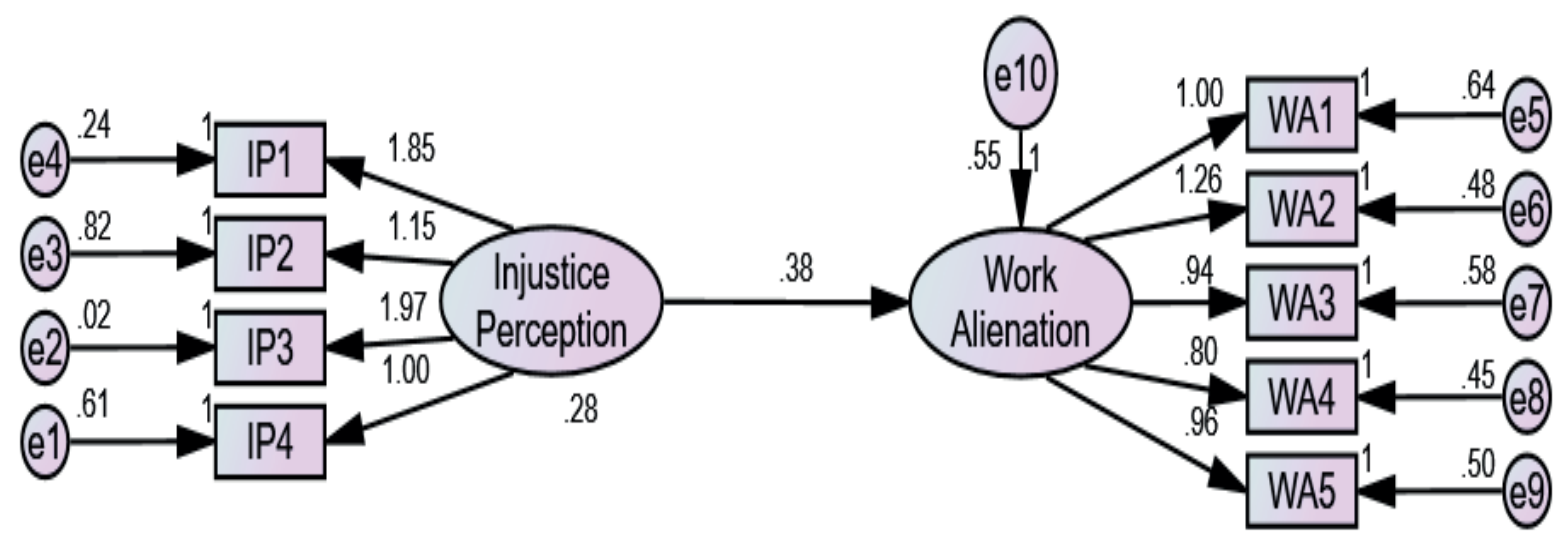

Figure 2: Tested Model A

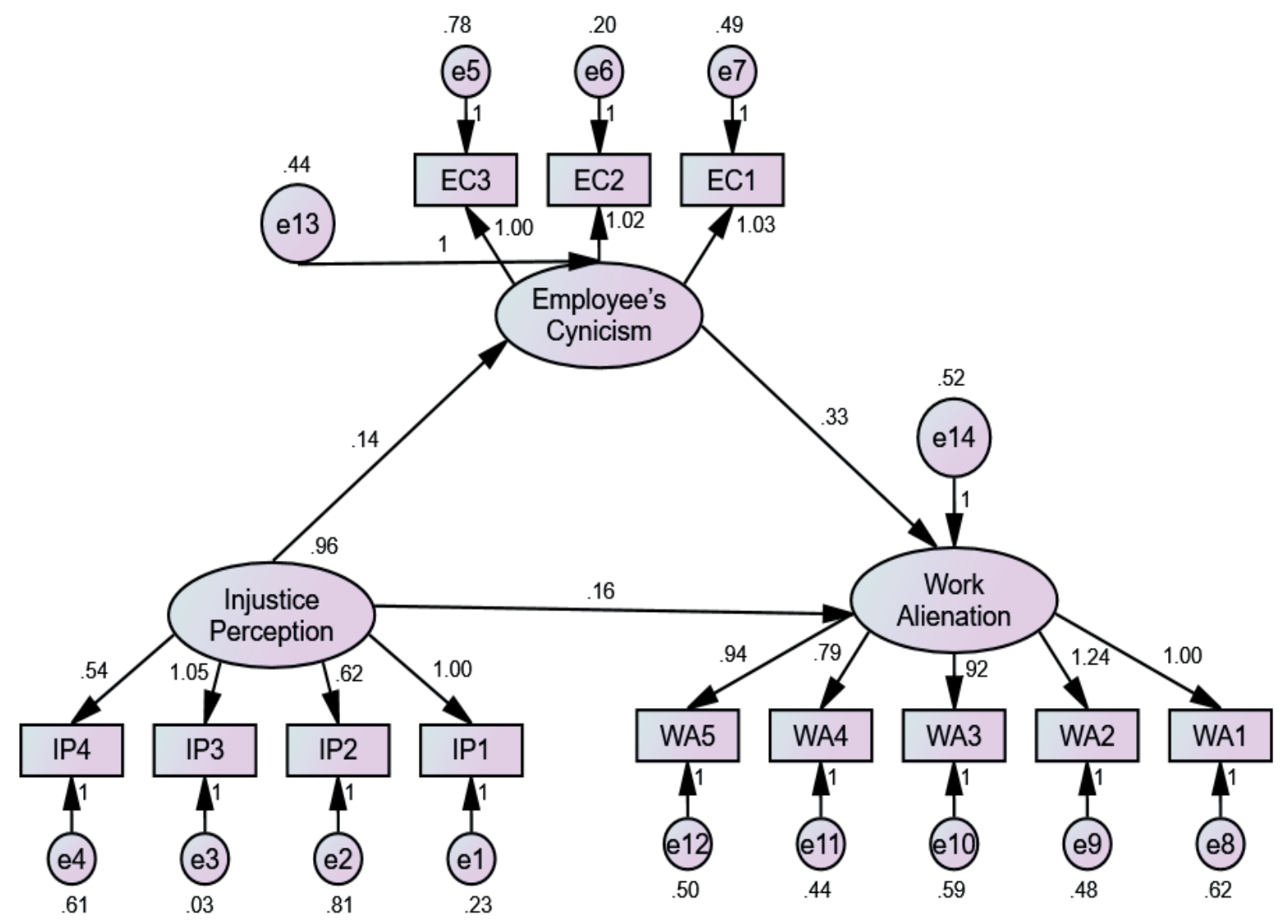

Figure 3: Tested Model B 
Table 5 illustrates fit indices for both models. Results show that all indices are above fit threshold level (Hair et al., 2006; Kline, 1999; Schermelleh-Engel \& Moosbrugger, 2003).

The findings obtained from direct effect and indirect effect are summarized in Table 6 . The accepted and/or rejected hypotheses are shown. Model A examined the effect of injustice perception on work alienation. The analysis of the direct path work alienation was found to be positively affected by injustice perception (Path coefficient $=.38$, T-value $=3.16$, $\mathrm{P}$-value $=.002)$ supporting the first hypothesis $\left(\mathrm{H}_{1}\right)$.

Model B explored the effect of employee's cynicism as a mediator in injustice perception and work alienation association. The analysis showed that injustice perception has a positively effect on employee's cynicism (Path coefficient .14, T-value $=2.26, \mathrm{P}$-value $=.024$ ) supporting the second hypothesis $\left(\mathrm{H}_{2}\right)$. Additionally, employee's cynicism significantly affects work alienation (Path coefficient $.33, \mathrm{~T}$-value $=3.12$, P-value $=.002)$. Thus, the third hypothesis $\left(\mathrm{H}_{3}\right)$ is also supported. The employee's cynicism partially mediated the relationship between injustice perception and work alienation (Path coefficient of .16, T-value $=2.59$, P-value $=.010$ ), with a coefficient of indirect effect $(.22)$ and ratio to total effect of 57.89 $\%$. Hence, the fourth hypothesis was partially supported (H4).

Table 5: Fit Indices of the Model

\begin{tabular}{|c|c|c|c|c|c|c|c|c|c|c|}
\hline Fit Indices & CMIN/DF & RMSEA & RMR & GFI & CFI & TLI & NFI & IFI & PGFI & PNFI \\
\hline Model 1 & 3.078 & .065 & .059 & .914 & .922 & .912 & .917 & .923 & .528 & .648 \\
\hline Model 2 & 4.751 & .076 & .067 & .915 & .919 & .902 & .907 & .921 & .559 & .624 \\
\hline Recommended & $<5$ & $<.08$ & $<.08$ & $>.90$ & $>.90$ & $>.90$ & $>.90$ & $>.90$ & $>.50$ & $>.50$ \\
\hline
\end{tabular}

Table 6: Direct and indirect effects

\begin{tabular}{|c|c|c|c|c|c|c|c|c|}
\hline Hypotheses & Path & $\begin{array}{l}\text { Direct } \\
\text { Effect }\end{array}$ & $\begin{array}{c}\text { Indirect } \\
\text { Effect }\end{array}$ & $\begin{array}{l}\text { Total } \\
\text { Effect }\end{array}$ & $\begin{array}{c}\text { Ratio of } \\
\text { Indirect } \\
\text { effect to total } \\
\text { effect }\end{array}$ & $\begin{array}{l}\text { T-Value } \\
\mathrm{T}>1.96\end{array}$ & $\begin{array}{l}\text { P-Value } \\
P<0.05\end{array}$ & Result \\
\hline $\begin{array}{l}\mathbf{H}_{1:} \text { Injustice } \\
\text { perception has a } \\
\text { significant effect on } \\
\text { work alienation. }\end{array}$ & $\underset{\mathrm{WA}}{\stackrel{\mathrm{IP}}{\longrightarrow}}$ & .38 & & & & 3.16 & .002 & Supported \\
\hline $\begin{array}{l}\mathrm{H}_{2:} \text { Injustice } \\
\text { perception has a } \\
\text { significant effect on } \\
\text { employee's cynicism. }\end{array}$ & $\underset{\mathrm{EC}}{\stackrel{\mathrm{IP}}{\longrightarrow}}$ & .14 & & & & 2.26 & .024 & Supported \\
\hline $\begin{array}{l}\mathbf{H}_{3:} \text { Employee's } \\
\text { cynicism has a } \\
\text { significant effect on } \\
\text { work alienation. }\end{array}$ & $\underset{\mathrm{WA}}{\mathrm{EC}}$ & .33 & & & & 3.12 & .002 & Supported \\
\hline $\begin{array}{l}\mathrm{H}_{4:} \text { Employee's } \\
\text { cynicism mediates } \\
\text { in the relationship } \\
\text { between injustice } \\
\text { perception and work } \\
\text { alienation. }\end{array}$ & $\underset{\mathrm{WA}}{\stackrel{\mathrm{IP}}{\longrightarrow}}$ & .16 & .22 & .38 & $57.89 \%$ & 2.59 & .010 & $\begin{array}{c}\text { Partial } \\
\text { Mediation }\end{array}$ \\
\hline
\end{tabular}




\section{Discussion and Conclusion}

The present study is novel in exploring the direct and indirect effect of injustice perception on work alienation through employee's cynicism in the healthcare sector in Oman. This study is pivotal and essential in private hospitals to understand the nurses' behaviors if they feel injustice and cynicism towards their organizations. Therefore, it is very important to evaluate the behaviors of nurses in the healthcare facilities to identify the factors that have major effects on them (Pham et al., 2020). Results of this research present considerable evidence to prove that injustice perception has a significant impact on work alienation. Likewise, the injustice perception helps in exploring organizational cynicism that in turn has an effect on work alienation.

The findings showed that the levels of injustice perception and cynicism in the private hospitals were generally low, while the work alienation was found to be at moderate level. The obtained results are consistent with the results from previous studies that showed a moderate familiarity of work alienation (Daglı \& Averbek, 2017; Valikhani \& Zamani, 2019), and the study by Durrah, Chaudhary, and Gharib (2019) that showed low level of organizational cynicism, while it differs in terms of perceiving injustice with the study by Sulu, Ceylan, and Kaynak (2010) that indicated moderate level of injustice perception.

The findings of this study are aligned with past research. This study proved that the injustice perception has a significant effect on alienation from work (Ceylan \& Sulu, 2011). In other words, the work alienation among nurses was seen to increase with an increase in the level of injustice perception. Also the findings substantiate that the cynicism significantly impacts work alienation (Yıldıza \& Şaylıkay, 2014) that means that work alienation among nurses increased as cynicism increased. Furthermore, injustice perception positively affects the cynicism (Joe-Akunne \& Oguegbe, 2019), which means that, as the injustice perception level of nurses increases, cynicism increases. Moreover, the study results revealed that the cynicism plays a mediating role in relationship between injustice perception and work alienation. Recently, these subjects are getting considerable attention (Dajani \& Mohamad, 2017; JoeAkunne \& Oguegbe, 2019; Yıldıza \& Şaylıkay, 2014).

\section{Theoretical and Practical Implications}

The results of this insightful study have multifold implications for the healthcare-providing organizations and the researchers in Oman. From the theoretical perspective, it provides an understanding of injustice perception and its relationships with the cynicism and work alienation. Previous studies have identified many indicators of work alienation. However, few studies have reported that injustice perception provides a main factor for work alienation (Ceylan \& Sulu, 2010; Dajani \& Mohamad, 2017). Furthermore, it also signifies the importance of cynicism in injustice perception and work alienation relationship among nurses. This study is among the first studies using a model developed on previous studies (Ceylan \& Sulu, 2011; Yıldıza \& Şaylıkay, 2014; Sazkaya, 2014) as a conceptual framework that combined three variables (injustice perception, cynicism, and work alienation) to examine the association between them. Hence, this research is novel as it opens new avenues of exploration. It also contributes to the present literature by exploring the healthcare sector in a developing country (Oman).

From a practical perspective, the findings of this study have interesting implications. The policymakers and managers in private healthcare sector are advised to focus on creating an organizational justice climate in the working environment by exerting great efforts to reduce the perceptions of injustice in the private hospitals (Dajani \& Mohamad, 2017) and reviewing the organizational policies and procedures to achieve the justice among nurses by providing career development programs and continuous training to nursing employees (Liao \& Rupp, 2005), and income equality and development of the staff (Nguyen et al., 2020). The private healthcare sector should monitor levels of work alienation in nurses by Human Resource interventions and adopting proactive counseling treatments as it might lead to job dissatisfaction (Whiteside and Barclay, 2013). Hence, special attention should be given to eliminate the factors that cause organizational cynicism and work alienation. Furthermore, the hospitals should acknowledge the importance of making the workplace a motivating factor for their employees and take corrective steps to ensure that the nurses participate in healthy condition to accomplish their job responsibilities. The private hospitals can decrease work alienation by reducing job pressure and cynicism in the working environment. This can be achieved by decreasing job stress and by increasing coworker trust (Kim et al., 2019). Moreover, cynicism and work alienation can be reduced by creating a healthy work environment for nurses by encouraging managers to behave justly (Koçoglu, 2014), and respect, proper words and actions are important in the relationship with the employees in the healthcare organizations (Lee \& Ha, 2020).

\section{Limitations and Future Studies Directions}

Despite the novelty of the study in its contextual field, the current study has some limitations that need to be highlighted. One of the most important limitations was that only four private hospitals in Salalah, Oman, were considered for study sample, thus, did not provided enough variability. Future studies may cover several hospitals in all governorates of Oman or GCC countries. Another limitation 
is that the study was applied to the private health sector only and this may be insufficient for the purposes of academic generalization. Therefore, in future studies, data should be collected from both governmental and private healthcare sectors. Also, it should consider other sectors like industry, hospitality, education, banking and the media. Finally, injustice perceptions, cynicism, and work alienation are still sensitive and discreet topics in the Omani culture, so, we suggest to use a behavioral observation method in addition to self-report surveys to assess these topics in future studies.

\section{References}

Abraham, R. (2000). Organizational cynicism: bases and consequences. Genetic, Social, and General Psychology Monographs, 126(3), 269-277.

Adams, J. (1965). Inequity in social exchange. Advances in Experimental Social Psychology, 2, 267-299.

Afrasiabi, H., Jamshidi, B., Suluklu, \& Ghudrati, H. (2013). Study of job satisfaction concerning participation and alienation among employees of Fars regional electric company. Applied Sociology, 24(49), 56-68.

Ahmed, W., Kiyani, A., \& Hashmi, S. (2013). The Study of organizational cynicism, organizational injustice and breach of psychological contract as the determinants of deviant work behavior. Actual Problems of Economics, 140 (2), 145-154.

Ajzen, I. (2001). Nature and operation of attitudes. Annual Review of Psychology, 52, 27-58.

Alraja, M., \& Kashoob, M. (2019). Transformation to electronic purchasing: an empirical investigation. Telkomnika, 17(3), 1209-1219.

Ambulkar, S., Blackhurst, J., \& Grawe, S. (2015). Firm's resilience to supply chain disruptions: Scale development and empirical examination. Journal of Operations Management, 33- 34, 111-122. https://doi.org/10.1016/j.jom.2014.11.002

Andersson, L., \& Bateman, T. (1997). Cynicism in the workplace: some causes and effects. Journal of Organizational Behavior, 18(5), 449-469.

Annual Health Report. (2018). Health Services by Other Health Care Providers. Ministry of Health, Muscat, Sultanate of Oman.

Aquino, K., Lewis, M., \& Bradfield, M. (1999). Justice constructs, negative affectivity, and employee deviance: A proposed model and empirical test. Journal of Organizational Behavior, 20(7), 1073-1091.

Bernerth, J., Armenakis, A., Field, H., \& Walker, H. (2007). Justice, cynicism, and commitment: A study of important organizational change variables. Journal of Applied Behavioral Science, 43, 303-326.

Bies, R., \& Moag, J. (1986). Interactional Justice: Communication Criteria of Fairness. In: R. J. Lewicki, B. H. Sheppard, \& M. H. Bazeman (Eds.), Research on Negotiations in Organizations (pp. 43-55). Greenwich, CT: JAI Press.
Bish, A., Newton, C., \& Johnston, K. (2015). Leader vision and diffusion of HR policy during change. Journal of Organizational Change Management, 28(4), 529-545.

Çetinkaya, F. (2018). Psychological Contract Breach and Organizational Cynicism Relationship. Journal of Business Research-Türk, 10(1), 652-674.

Ceylan, A., \& Sulu, S. (2010). Work Alienation as a mediator of the relationship of procedural injustice to job stress. South East European Journal of Economics and Business, 5(2), 65-74.

Ceylan, A., \& Sulu, S. (2011). Organizational injustice and work alienation. E + M Ekonomika A Management, 2, 65-78.

Chan, T., Cheung, C., Shi, N., \& Lee, M. (2015). Gender differences in satisfaction with Facebook users, Industrial Management and Data Systems, 115(1), 182-206.

Cohen-Charash, Y., \& Spector, P. (2001). The role of justice in organizations: A meta-analysis. Organizational Behaviour and Human Decision Processes, 86(2), 278-321.

Crino, M. (1994). Employee sabotage: a random or preventable phenomenon? Journal of Managerial, 6, 311-330.

Cropanzano, R., \& Mitchell, M. (2005). Social exchange theory: An interdisciplinary review. Journal of Management. 31, 874-900.

Dagl1, A., \& Averbek, E. (2017). The Relationship between the Organizational Alienation and the Organizational Citizenship Behaviors of Primary School Teachers. Universal Journal of Educational Research, 5(10), 1707-1717.

Dajani, M., \& Mohamad, M. (2017). Perceived organizational injustice and counterproductive behavior: the mediating role of work alienation evidence from the Egyptian. International Journal of Business and Management; 12(5), 192-201.

Dean J., Brandes, P., \& Dharwadkar, R. (1998). Organizational cynicism. The Academy of Management Review, 23(2), 341-352.

DeHart-Davis, L., \& Pandey, S. (2005). Red tape and public employees: Does perceived rule dysfunction alienate managers? Journal of Public Administration Research and Theory, 15(1), 133-148.

Durrah, O., Allil, K., Gharib, M., \& Hannawi, S. (2020a). Organizational pride as an antecedent of employee creativity in the petrochemical industry. European Journal of Innovation Management. [In Press] doi.org/10.1108/EJIM-08-2019-0235

Durrah, O., Chaudhary, M., \& Gharib, M. (2019). Organizational cynicism and its impact on organizational pride in industrial organizations. International Journal of Environmental Research and Public Health, 16(7), 1-16.

Durrah, O., Eltigani, M., Gharib, M., \& Hannawi, S. (2020b). Management by walking around as an approach to improving organizational excellence in media institutions. Journal of Economic, Administrative and Legal Sciences, 4(4), 147-165.

Dwivedi, Y., Choudrie, J., \& Brinkman, W. (2006). Development of a survey instrument to examine consumer adoption of broadband. Industrial Management \& Data Systems, 106(5), 700-718. 
Elovainio, M., Kivimaki, M., Steen, N., \& Vahtera, J. (2004). Job decision latitude, organizational justice and health: multilevel covariance structure analysis. Social Science and Medicine, 58, 1659-1669.

Farahbod, F., Azadehdel, M., Chegini, M., \& Ashraf, A. (2012). Work alienation historical backgrounds, concepts, reasons and effects. Journal of Basic and Applied Scientific Research, 2(12), 408-8415.

Feldman, D. (2000). The Dilbert syndrome: How employee cynicism about ineffective management is changing the nature of careers in organizations. American Behavioral Scientist, 43(8), 1286-1300.

Field, A. (2005). Discovering Statistics Using SPSS. (2 $2^{\text {nd }}$ ed.). London, UK: Sage Publications.

Fox, S., Spector, P., \& Miles, D. (2001). Counterproductive work behavior in response to job stressors and organizational justice: some mediator and moderator tests for autonomy and emotions. Journal of Vocational Behavior, 59, 291-309.

Furnham, A., \& Siegel, E. (2011). Reactions to organizational injustice: counter work behaviors and the insider threat. In: E. Kals \& J. Maes (Eds.), Justice and Conflicts. Berlin, Germany: Springer, https://doi.org/10.1007/978-3-642-19035-3_12

Geyer, R. (1996). Alienation, Ethnicity, and Postmodernism. Westport, CT: Greenwood Pub Group.

Ghasemi, A., \& Zahediasl, S. (2012). Normality tests for statistical analysis: A guide for non-statisticians. International Journal of Endocrinology and Metabolism, 10, 486-489.

Ghouse, S., McElwee, G., \& Durrah, O. (2019). Entrepreneurial success of cottage-based women entrepreneurs in Oman. International Journal of Entrepreneurial Behavior and Research, 25(3), 480-498.

Greenberg, J. (2004). Stress fairness to fare no stress: managing workplace stress by promoting organizational justice. Organizational Dynamics, 33(4), 352-365.

Hackman, J., \& Oldham, G. (1980). Work Redesign. Boston, MA: Addison-Wesley.

Hair, J., Black, W., \& Babin, B. (2010). Multivariate Data Analysis: A Global Perspective, London, UK: Pearson Education.

Hair, J., Black, W., Babin, B., Anderson, R., \& Tatham, R. (2006). Multivariate Data Analysis. Upper Saddle River, NJ: Pearson Prentice Hall.

Haslam, S. (2004). Psychology in Organizations: The Social Identity Approach. London, UK: Sage Publications Ltd.

Hegel, G. (2003). The Phenomenology of Mind. Dover, UK: Dover Publications.

Hirschfeld, R. Feild, H., \& Bedeian, A. (2000). Work alienation as an individual-difference construct for predicting workplace adjustment: a test in two samples. Journal of Applied Social Psychology, 30(9), 1880-1902.

Hu, L., \& Bentler, P. (1999). Cutoff criteria for fit indexes in covariance structure analysis: conventional criteria versus new alternatives, Structural Equation Modeling. A Multidisciplinary Journal, 6(1), 1-55.

Hull, J., Van Treuren, R., \& Virnelli, S. (1987). Hardiness and health: A critique and alternative approach. Journal of Personality and Social Psychology, 53(3), 518-523.

Information and Statistics Department. (2012). Annual Health Report. Ministry of Health, Muscat, Sultanate of Oman.

Joe-Akunne, C., \& Oguegbe, T. (2019). Organizational cynicism and interactional injustice as correlates of workplace deviance among private company employees. Journal of Industrial and Organizational Behavior in Africa, 1(1), 163-178.

Jones, D. (2008). Getting even with one's supervisor and one's organization: relationships among types of injustice, desires for revenge, and counterproductive work behaviors. Journal of Organizational Behavior, 30, 525-542.

Kanungo, R. (1982). Work Alienation: An Integrative Approach. New York, NY: Praeger Publishers.

Kelloway, E., Barling, J., \& Hurrell, J. (2006). Handbook of Workplace Violence, Thousand Oaks, CA: Sage Publications.

Khdour, N., Durrah, O., \& Harris, M. (2015). The effect of job burnout on employees' satisfaction: a comparison study between public universities and private universities in Jordan. Journal of Management Research, 7(4), 54-81.

Kickul, J., Gundry, L. K., \& Posig, M. (2005). Does trust matter? the relationship between equity sensitivity and perceived organizational justice. Journal of Business Ethics, 56, 205-218.

Kim, S., Jung, K., Noh, G., \& Kang, L. (2019). What makes employees cynical in public organizations? Antecedents of organizational cynicism. Social Behavior and Personality: An International Journal, 47(6), 1-10.

Kline, R. (1999). Software review: software programs for structural equation modeling: AMOS, EQS, and LISREL. Journal of Psychoeducational Assessment, 16(4), 343-364.

Kobasa, S., Maddi, S., \& Kahn, S. (1982). Hardiness and health: a prospective study. Journal of Personality and Social Psychology, 42(1), 168-174.

Koçoglu, M. (2014). Cynicism as a mediator of relations between job stress and work alienation: a study from a developing country - Turkey. Global Business and Management Research: An International Journal, 6(1), 24-36.

Lee, C., \& Ha, B. (2020). The impact of interactional justice and supply chain collaboration on sustainable SCM performance: the case of multinational pharmaceutical firms. Journal of Asian Finance, Economics and Business, 7(2), 237-247. https:// doi.org/10.13106/jafeb.2020.vol7.no2.237

Li, F., \& Fan Zhou, K. (2011). Expecting the worst: moderating effects of social cynicism on the relationships between relationship conflict and negative affective reactions. Journal of Business and Psychology, 26, 339-345.

Liao, H., \& Rupp, D. (2005). The impact of justice climate and justice orientation on work outcomes: Across-level multifoci framework. Journal of Applied Psychology, 90(2), 242-256. 
Mau, R. (1992). The validity and devolution of a concept: Student alienation. Adolescence, 27(107), 731-741.

Merkhe, J. (2015). The impact of perception of organizational injustice on work alienation: analytical study at international schools in Amman. Master's Theses. Middle East University, Jordan.

Mingzheng, W., Xiaoling, S., Xubo, F., \& Youshan, L. (2014). Moral identity as a moderator of the effects of organizational injustice on counterproductive work behavior among Chinese public servants. Public Personnel Management, 43(3), 314-324.

Nguyen, T., Nguyen, T., Nguyen, T., \& Nguyen, V. (2020). The impact of international integration on the inequality of income between rural and urban areas in Vietnam. Journal of Asian Finance, Economics and Business, 7(3), 277-287. https://doi. org/10.13106/jafeb.2020.vol7.no3.277

Ozer, O., Ugurluoglu, O., Sayg1l1, M., \& Songur, C. (2019). The impact of work alienation on organizational health: A field study in health sector. Journal International Journal of Healthcare Management, 12(1), 18-24.

Ozler, D., \& Atalay, C. (2011). A research to determine the relationship between organizational cynicism and burnout levels of employees in health sector. Business and Management Review, 1(4), 26-38.

Pham, C., Vu, S., Pham, Y., \& Vu, N. (2020). Evaluating performance of Vietnamese public hospitals based on balanced scorecard. Journal of Asian Finance, Economics and Business, 7(6), 339349. https://doi.org/10.13106/jafeb.2020.vol7.no6.339

Planning Agency. (2014). Future Outlook for the Health System (Health 2050), Ministry of Health, Sultanate of Oman.

Podsakoff, P., MacKenzie, S., \& Podsakoff, N. (2012). Sources of method bias in social science research and recommendations on how to control It. Annual Review of Psychology, 63(1), 539-569.

Preacher, K., \& Hayes, A. (2008). Asymptotic and resampling strategies for assessing and comparing indirect effects in multiple mediator models. Behavior Research Methods, 40(3), 879-891.

Pugh, S., Skarlicki, D., \& Passell, B. (2003). After the fall: layoff victims' trust and cynicism in re-employment. Journal of Occupational and Organizational Psychology, 76(2), 201-212.

Punia, P., \& Berwal, S. (2017). Development and standardization of an alienation scale for visually impaired students. Journal of Visual Impairment and Blindness, September-October, 427-439.

Sanal, M., \& Zare, L. (2017). Organizational alienation. International Journal of Business and Management Invention, 6(4), 105-112.

Sazkaya, M. (2014). Cynicism as a mediator of relations between job stress and work alienation: a study from a developing country - Turkey. Global Business and Management Research: An International Journal, 6(1), 24-36.
Schermelleh-Engel, K., \& Moosbrugger, H. (2003). Evaluating the fit of structural equation models: tests of significance and descriptive goodness-of-fit measures. Methods of Psychological Research Online, 8(2), 23-74.

Schmitt, M., \& Dorfel, M. (1999). Procedural injustice at work, justice sensitivity, job satisfaction and psychosomatic wellbeing. European, Journal of Social Psychology, 29, 443-453.

Seeman, M. (1971). The urban alienations: Some dubious theses from Marx to Marcuse. Journal of Personality and Social Psychology, 19(2), 135-143.

Skarlicki, D., Van Jaarsveld, D., \& Walker, D. (2008). Getting even for customer mistreatment: the role of moral identity in the relationship between customer interpersonal injustice and employee sabotage. Journal of Applied Psychology, 93(6), 1335-1347.

Sookoo, N. (2014). Perceptions of injustice and alienation dynamics within the workplace. Journal of the Department of Behavioural Sciences, 3(1), 81-99.

Stanley, D., John, P., \& Laryssa, T. (2005). Employee cynicism and resistance to organizational change. Journal of Business and Psychology, 19(4), 429-459.

Straub, D., Boudreau, M., \& Gefen, D. (2004). Validation guidelines for is positivist research. Communications of the Association for Information Systems, 13(6), 380-427.

Subgur, C., Ozer, O., Saygili, M., \& Ugurlouglu, O. (2019). Paternalistic leadership, organizational cynicism, and intention to quit one's job in nursing. Hospital Topics, 97(4), 139-147.

Sulu, S., Ceylan, A., \& Kaynak, R. (2010). Work alienation as a mediator of the relationship between organizational injustice and organizational commitment: implications for healthcare professionals. International Journal of Business and Management, 5(8), 27-38.

Tabrizi, A. (1991). Alienation, Conceptualization, and Grouping of Theories in the Fields of Sociology and Psychology. Social Sciences, 2, 25-73.

Tepper, B. (2001). Health consequences of organizational injustice: tests of main and interactive effects. Organizational Behavior and Human Decision Processes, 86, 197-215.

Tucker, J. (1993). Everyday forms of employee resistance. Sociological Forum, 8, 25-45.

Tukelturk, Ş., Perçin, N., \& Güzel, B. (2012). Psychological Contract breaches and organizational cynicism at hotels. The Young Economists Journal, 9(19), 194-213.

Tulsi, P., \& Ji, Y. (2020). A conceptual approach to green human resource management and corporate environmental responsibility in the hospitality industry. Journal of Asian Finance, Economics and Business, 7(1), 195-203. https://doi. org/10.13106/jafeb.2020.vol7.no1.195

Tummers, L., \& den Dulk, L. (2013). The effects of work alienation on organizational commitment, work effort and work-to-family enrichment. Journal of Nursing Management, 21, 850-859. 
Tummers, L. (2011). Explaining the willingness of public professionals to implement new policies: A policy alienation framework. International Review of Administrative Sciences, 77(3), 555-581.

Tummers, L., Bekkers, V., van Thiel, S., \& Steijn, B. (2015). The effects of work alienation and policy alienation on behavior of public employees. Administration and Society, 47(5), 596-617.

Valikhani, M., \& Zamani, S. (2019). Investigation of demographic factors influencing the work alienation among Isfahan Tejarat Bank employees. Qualitative Research Journal, 4(5), 1-6.

Whiteside, D., \& Barclay, L. (2013). Echoes of silence: employee silence as a mediator between overall justice and employee outcomes. Journal of Business Ethics, 116(2), 251-266.

World Health Organization. (WHO). (2013). World Health Statistics. Retrieved April 10, 2020 from: https://www.who.int/ gho/publications/world_health_statistics/en/

Yıldıza, S., \& Şaylıkay, M. (2014). The effect of organizational cynicism on alienation. Procedia - Social and Behavioral Sciences, 9, 622-627.

Zellars, K. L., Liu, Y., Bratton, V., Brymer, R., \& Perrewé, P. L. (2004). An examination of the dysfunctional consequences of organizational injustice and escapist coping. Journal of Managerial Issues, 16(4), 528-544. 